\title{
LA-UR-14-28435
}

Approved for public release; distribution is unlimited.

Title:

Author(s):

Intended for:
Course Overview and Objectives

\section{Santi, Peter Angelo}

International Training Course on Implementating State Systems of Accounting for and Control (SSAC) of Nuclear Material for States with Small Quantity Protocols (SQP), November 2-7, 2014, Santa Fe, NM

Issued: 
Disclaimer:

Los Alamos National Laboratory, an affirmative action/equal opportunity employer,is operated by the Los Alamos National Security, LLC for the National NuclearSecurity Administration of the U.S. Department of Energy under contract DE-AC52-06NA25396. By approving this article, the publisher recognizes that the U.S. Government retains nonexclusive, royalty-free license to publish or reproduce the published form of this contribution, or to allow others to do so, for U.S. Government purposes. Los Alamos National Laboratory requests that the publisher identify this article as work performed under the auspices of the U.S. Departmentof Energy. Los Alamos National Laboratory strongly supports academic freedom and a researcher's right to publish; as an institution, however, the Laboratory does not endorse the viewpoint of a publication or guarantee its technical correctness. 


\section{Course Overview and Objectives}

International Training Course on

Implementing State Systems of Accounting for and Control (SSAC) of Nuclear Material for States with Small Quantity Protocols (SQP)

Los Alamos National Laboratory

Peter Santi 


\section{Satellite View of Northern New Mexico}

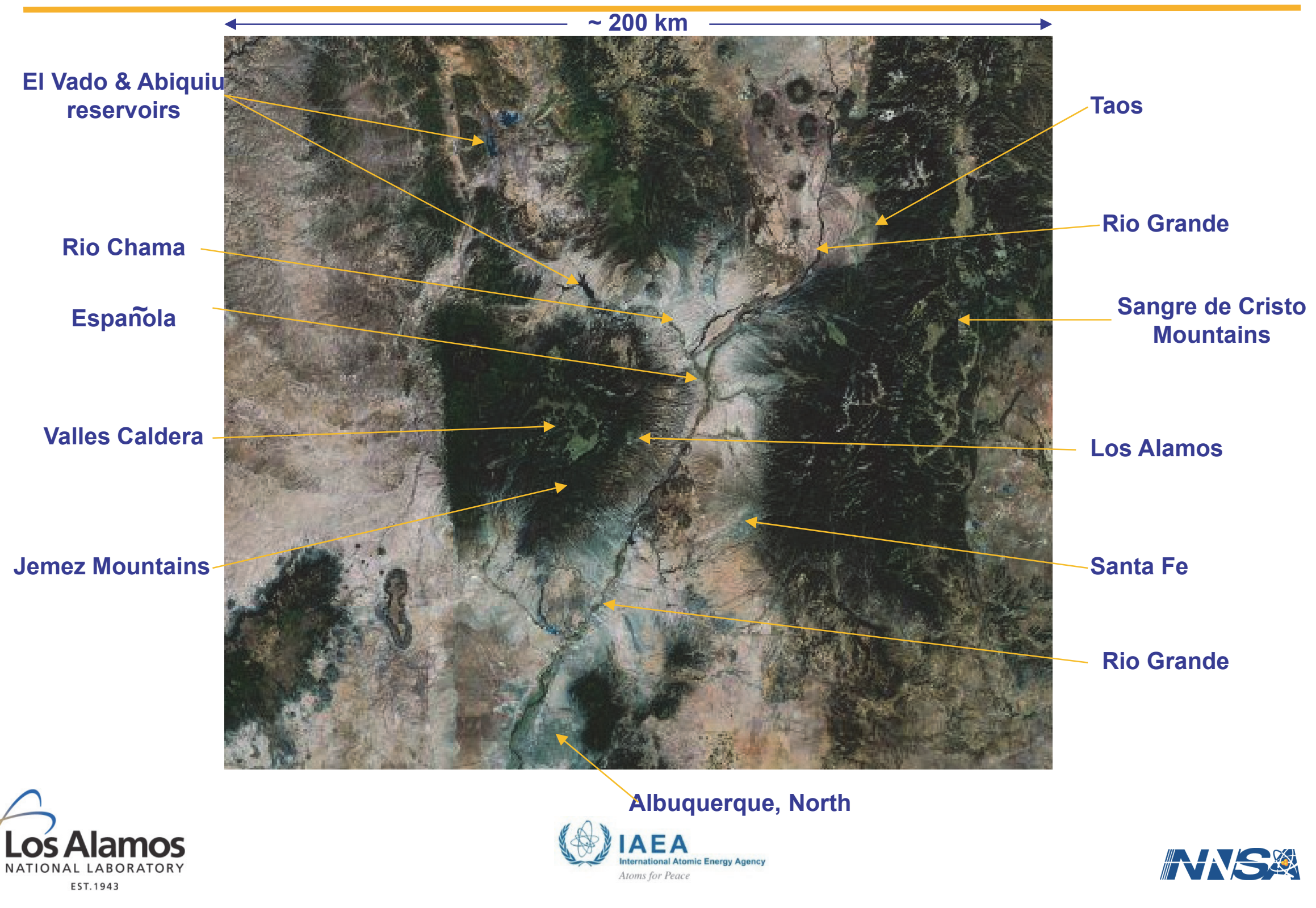




\section{Staying in New Mexico}

- Santa Fe is located 2134 meters (7,199 feet) above sea level (Los Alamos 7,320 feet)

- Altitude + low humidity = higher risk of dehydration.

- Lightning 


\section{Foreign National Requirements}

- U.S. immigration law requires that all foreign nationals at all times possess their passport. 


\section{Course Overview}

- This course is hosted by Los Alamos National Laboratory on behalf of the U.S. National Nuclear Security Administration (NNSA) in collaboration with the IAEA to support Member States in managing small quantities of nuclear and radioactive materials in a manner that is compliant with their international obligations. 


\section{Nuclear Safeguards at LANL}

- The nuclear safeguards program at Los Alamos was started in 1966 by Bob Keepin,

- Keepin had just returned from a two-year stint as the head of the physics section at the IAEA and recognized the need for a safeguards program.
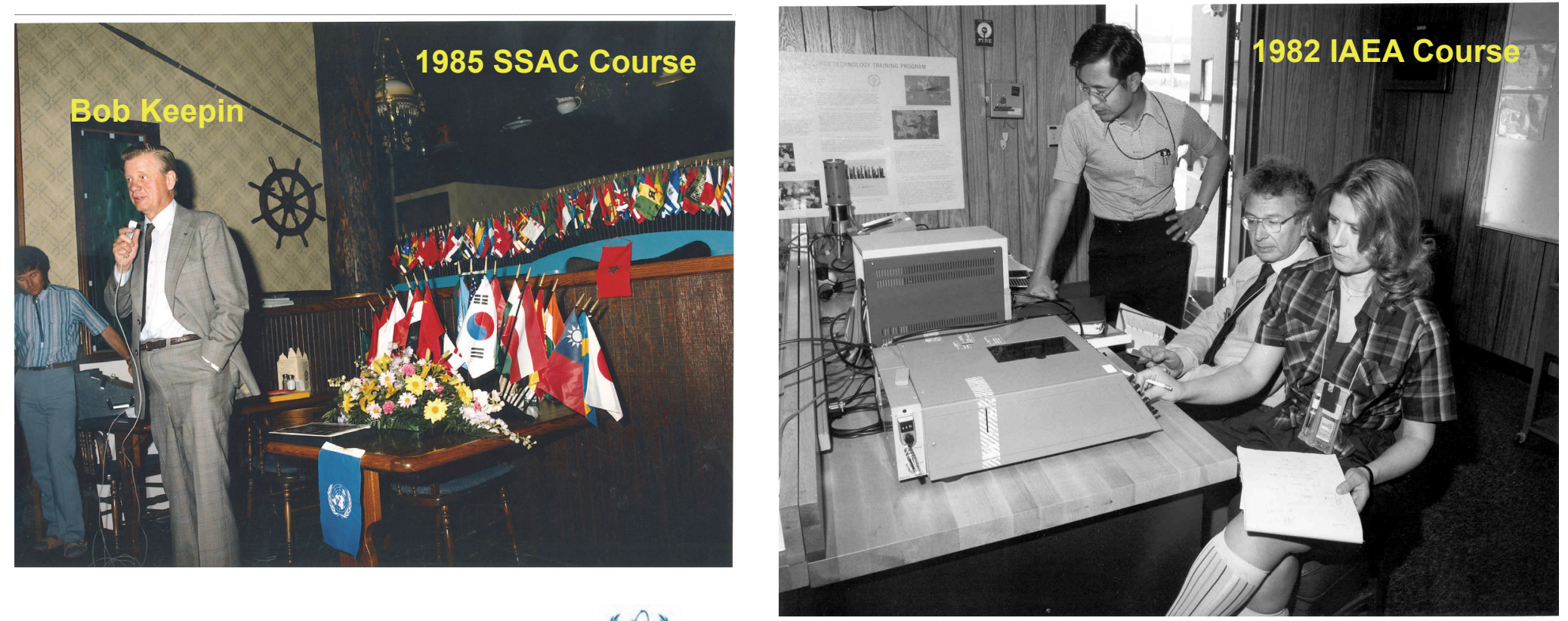


\section{LANL Safeguards Training Program}

- Domestic training began in 1973

- IAEA inspectors participation began in 1974

- Dedicated IAEA NDA training for inspectors began in 1980

- offered 56 times

- Every new IAEA inspector since 1980 has taken the course

- SSAC course 1980-2009; SQP course

- Since its inception in 1973, LANL has conducted $>310$ courses, $>5400$ students 


\section{Course Objectives}

- Identify international legal instruments for nuclear safeguards

- Describe the main obligations under the Non-Proliferation Treaty

- Define the essential elements of an effective State System of Accounting and Control (SSAC) for states following the Small Quantity Protocol (SQP) 


\section{Course Objectives}

- Identify and describe Fundamental Principles of Nuclear Material Control

- Basics of licensing or authorizing possession and use of nuclear material.

- Describe safeguards-related activities of operators or licensees/permit holders

- Define basic elements of an Information Management System supporting SSAC 


\section{Course Objectives}

- Explain reporting requirements of a State with a SQP

- Define nuclear material subject to safeguards

- List potential institutions that might use or store nuclear material

- Discuss the initial report

- Describe Additional Protocol reporting requirements

- Discuss support activities for IAEA access 


\section{Course Agenda}

\begin{tabular}{|l|l|l|l|l|}
\hline Date & $\begin{array}{l}\text { Session } \\
\text { Number }\end{array}$ & Lecture & Responsible \\
\hline $\begin{array}{l}\text { Sunday, } \\
\text { November 2 }\end{array}$ & Course Registration & $3: 00-5: 00 p m$ \\
\hline & & $\begin{array}{l}\text { Welcome Address } \\
\text { Introduction of Participants }\end{array}$ & All \\
\hline & Course Overview and Objectives & Peter Santi, LANL & 5:30pm & Nancy Jo Nicholas, LANL 6:00pm \\
\hline & Opening Remarks and Keynote Presentation & 6:30pm & IAEA (host) \\
\hline
\end{tabular}

\begin{tabular}{|l|l|l|l|l|}
\hline $\begin{array}{l}\text { Monday, } \\
\text { November } 3\end{array}$ & & Module 1: Legal and Regulatory Framework for Safeguards & Responsible \\
\hline & 1.1 & Introduction to IAEA Safeguards & John Lepingwell \\
\hline & & Break/Course Photo & $9: 00-10: 30 a m$ \\
\hline & 1.2 & MS Experience in Implementing Safeguards & (TBD) & Rebecca Stevens \\
\hline & 1.3 & Group Discussion on State Structures for SSAC & 11:15-11:30am & 11:30am-1:00pm \\
\hline & & Lunch & & \\
\hline & 2.1 & Role of the SRA in Implementing Safeguards & Stevens \\
\hline & 2.2 & Applications of Nuclear Material & Lepingwell \\
\hline & & Break & 2:00-2:45pm & IAEA/all \\
\hline
\end{tabular}

Los Alamos

NATIONAL LABORATORY
IAEA

intemationit A tomic Energy Agency

Atoms for Peace 


\section{Course Agenda}

\begin{tabular}{|c|c|c|c|c|}
\hline \multirow[t]{3}{*}{$\begin{array}{l}\text { Tuesday, } \\
\text { November } 4\end{array}$} & & & Responsible & Time \\
\hline & & Summary of Day 1 & & 9:00-9:30am \\
\hline & & Module 3: Accounting and Control of Nuclear Material & & \\
\hline & 3.1 & Nuclear Fuel Cycle & Deborah Dale, LANL & 9:30-10:15am \\
\hline & 3.2 & Exercise: Starting Point of Safeguards & Stevens & 10:15-10:45am \\
\hline & & Break & & 10:45-11:00am \\
\hline & 3.3 & Fundamentals of Nuclear Material Accounting and Control & Tomas Stepanek & 11:00-12:00am \\
\hline & & Lunch & & 12:00-1:30pm \\
\hline & 3.4 & WORKSHOP-Controlling Nuclear Material (initial report) & Stepanek & 1:30-3:00pm \\
\hline & & Break & & 3:00-3:15pm \\
\hline & 3.4 & WORKSHOP - Controlling Nuclear Material (inventory changes) & Stepanek & 3:15-4:00pm \\
\hline & & Module 4: Provision of Information & & \\
\hline & 4.1 & WORKSHOP - Reporting Nuclear Material & Stepanek & 4:00-5:00pm \\
\hline
\end{tabular}

- Los Alamos

NATIONAL LABORATORY
IAEA

Atoms for Peace 


\section{Course Agenda}

\begin{tabular}{|c|c|c|c|c|}
\hline $\begin{array}{l}\text { Wednesday, } \\
\text { November } 5\end{array}$ & & & Responsible & Time \\
\hline & & Summary of Day 2 & & 9:00-9:30am \\
\hline & 4.2 & Overview of Additional Protocol Requirements & Lepingwell & 9:30-10:30am \\
\hline & 4.3 & Declarability Exercise + Protocol Helper & $\begin{array}{l}\text { Kimberly Gilligan/ } \\
\text { Mark Killinger }\end{array}$ & 10:15-10:45am \\
\hline & & Break & & 10:45-11:00am \\
\hline & 4.4 & Introduction to Additional Protocol Workshop & Stepanek & 11:00-11:15am \\
\hline & 4.4 & Additional Protocol Workshop (continued) & Stepanek & 11:15am-12:00pm \\
\hline & & Lunch & Stepanek & 12:00-1:30pm \\
\hline & 4.4 & Additional Protocol Workshop (continued) & Stepanek & 1:30-4:30pm \\
\hline
\end{tabular}

\begin{tabular}{|l|l|l|l|l|}
\hline $\begin{array}{l}\text { Thursday, } \\
\text { November } 6\end{array}$ & & & Responsible & \\
\hline & & Summary of Day 3 & $90-9: 30 a m$ \\
\hline & & Module 5: Provision of Access and cooperation & \\
\hline & 5.1 & IAEA Nuclear Material Verification, Complementary Access & Lepingwell & Dale \\
\hline & 5.2 & Exercise on Complementary Access & $9: 30-10: 30$ am & 10:15am-12:00pm \\
\hline & & Lunch with Keynote Speaker: Alan Carr (LANL) & 12:00-1:30pm & LANL \\
\hline & & Tour of the Bradbury Science Museum & $1: 30-5: 30 p m$ & \\
\hline
\end{tabular}




\section{Course Agenda}

\begin{tabular}{|l|l|l|l|l|}
\hline $\begin{array}{l}\text { Friday, } \\
\text { November 7 }\end{array}$ & & & Responsible \\
\hline & & Summary of Day 4 & 9:00-9:30am \\
\hline & 5.3 & $\begin{array}{l}\text { Overview of Key Steps in the Implementation of Safeguards } \\
\text { Obligations (summary) }\end{array}$ & Stevens \\
\hline & 5.4 & Exercise: Establishment of an SSAC (wrap-up) & Dale & All \\
\hline & & Group Presentations & $10: 15-11: 00$ am \\
\hline & Lunch & $11: 00$ am-12:30pm \\
\hline & & Course Wrap-up and Certificates & & \\
\hline & End of Course & & \\
\hline
\end{tabular}




\section{Thanks and Good Luck}

Finally, this is your course, ask questions, learn, and have fun!

Enjoy New Mexico

$\mathscr{L a}$ Tiena Encantada 